\title{
6645309
}

AEC RESEARCH AND DEVELOPMENT REPORT

\section{A SCRAM BYPASS SYSTEM \\ USING ZENER DIODES AS LOGIC ELEMENTS}

W. J. Woodward
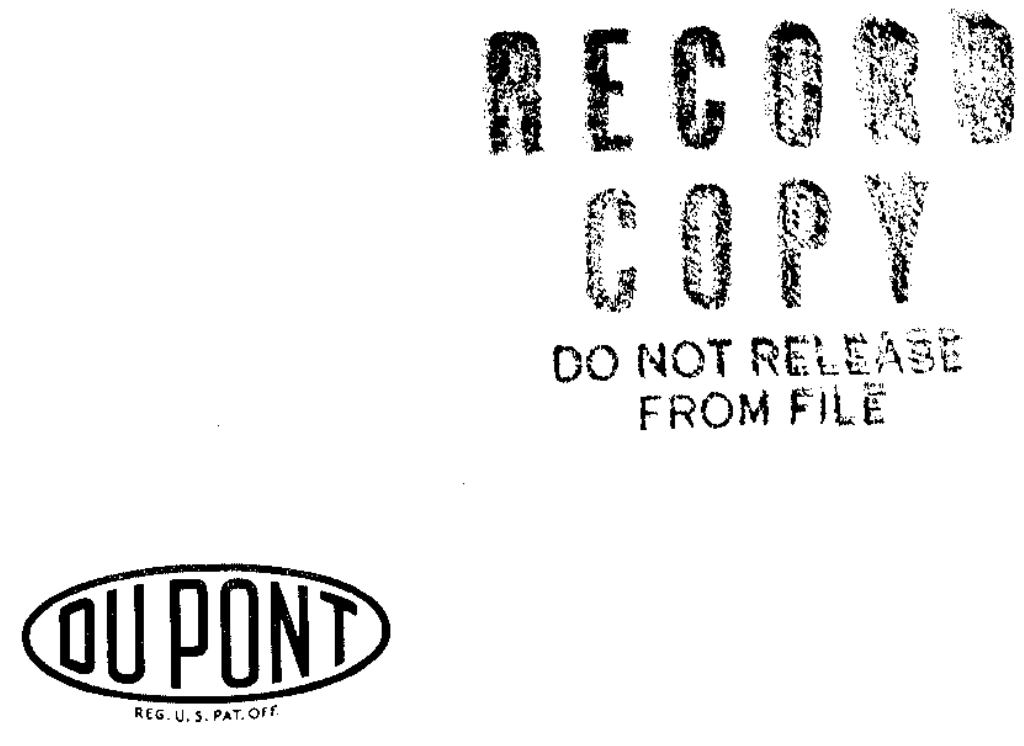

Savannah River Laboratory

Aiken, South Carolina 


\section{LEGAL NOTICE}

This report was prepared as an account of Government sponsored work. Neither the United States, nor the Commission, nor any person acting on behalf of the Commission:

A. Makes any warranty or representation, expressed or implied, with respect to the accuracy, completeness, or usefulness of the information contained in this report, or that the use of any information, apparatus, method, or process disclosed in this report may not infringe privately owned rights; or

B. Assumes any liabilities with respect to the use of, or for damages resulting from the use of any information, apparatus, method, or process disclosed in this report.

As used in the above, "person acting on behalf of the Commission" includes any employee or contractor of the Commission, or employee of such contractor, to the extent that such employee or contractor of the Commission, or employee of such contractor prepares, disseminates, or provides access to, any information pursuant to his employment or contract with the Commission, or his employment with such contractor.

Printed in USA. Price $\$ 1.00$

Avallable from the Clearinghouse for Federal Sclentific and Technical Information, National Bureau of Standards,

U. S. Department of Commerce, Springfield, Virginia 


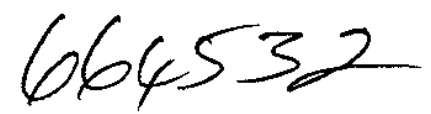

DP-926

Instruments

(TID-4500, 4lst Ed.)

\author{
A SCRAM BYPASS SYSTEM \\ USING ZENER DIODES AS LOGIC ELEMENTS \\ by \\ W1IIlam J. Woodward \\ Approved by \\ D. E. Waters, Manager \\ Laboratory Operations and Services
}

June 1965

\author{
E. I. DU PONT DE NEMOURS \& COMPANY \\ SAVANNAH RIVER LABORATORY \\ AIKEN, SOUTH CAROLINA \\ CONTRACT AT(07-2).1 WITH THE \\ UNITED STATES ATOMIC ENERGY COMMISSION
}




\begin{abstract}
A control chassis containing a group of reactor scram relays is described. A bypass switch is provided for each of the relays, but a zener diode logic circuit requires a certain minimum number of relays not to be bypassed before the reactor can be started up. The reactor is scrammed when any one of the unbypassed relays calls for a scram, or when less than the minimum number of scram relays is in service.
\end{abstract}




\section{A SCRAM BYPASS SYSTEM \\ USING ZENER DIODES AS LOGIC ELEMENTS}

\section{DISCUSSION}

At the Savannah River Laboratory it is desired to operate a certain test reactor only if three or more nuclear trips(1) are operating in the scram system. It is further desired that the reactor operator maintain positive control of the choice and number of these trips. A special chassis has been installed in the reactor control room to permit this type of operation.

The chassis contains a master scram relay and seven individual scram relays, one for each of seven nuclear instrument trips (Figure I). The front panel of the control unit is equipped with seven key-operated switches and seven sets of indicator lamps. The switches are two-position types marked "READY" and "BYPASS", and the 21 indicator lamps are marked and colored as follows: "SCRAM" is red, "READY" is green, and "BYPASSED" is amber. The panel is positioned so that the reactor operator can visually verify the condition of each circuit.

The switches cannot be operated without their keys, which the operator may keep in his possession for positive control. Logic circuits within the chassis cause the master relay to scram the reactor (or prevent its startup) if more than four switches are in "BYPASS" position simultaneously.

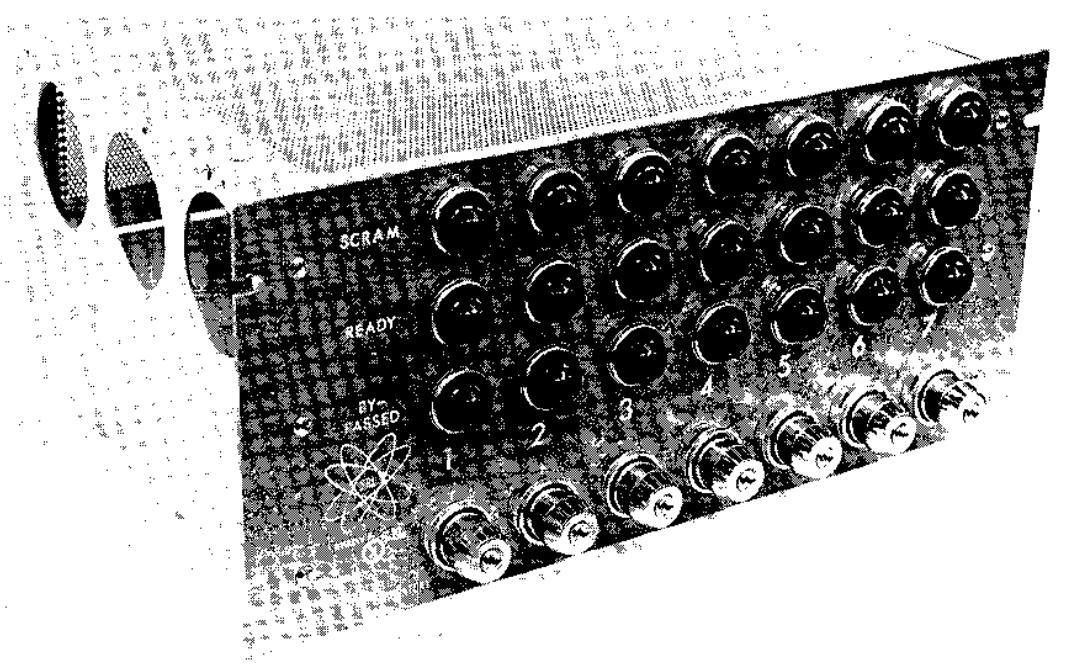

FIG. 1 CONTROL CHASSIS, SHOWING FRONT PANEL 


\section{CIRCUIT DESCRIPTION}

Figure 2 shows the chassis external connections through barrier-type terminal strips on the rear apron. The lndividual scram relays are plug-in types, and Figure 3 shows their interconnections. Master relay power comes from a self-contained DC supply, consisting of isolation transformer, silicon diode bridge, and filter capacitor. AC leads to this supply and to the lamps are fused separately.

The master relay coil is operated through zener diodes Zl through $\mathrm{Z8}$. ZI through $\mathrm{Z7}$ are 30-volt types, and the bypass switches are arranged to bypass them in the "READY" position. $\mathrm{Z} 8$ is an 18-volt unit that is not bypassed so that its voltage drop is added to the drop across the remainder of the series clrcuit. Master relay RY 8 operates at 24 volts and drops out at 10 volts. Thus, if four of the 30-volt diodes are not bypassed, the total diode voltage drop will be

$$
4(30)+18=138 \text { volts. }
$$

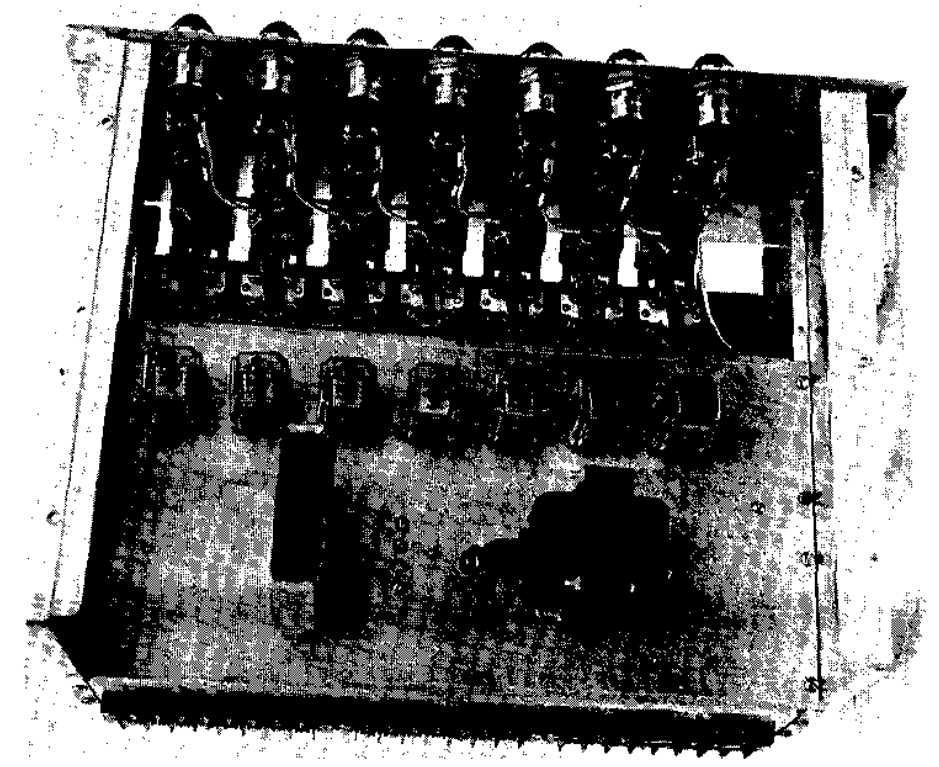

FIG. 2 TOP REAR VIEW, SHOWING EXTERNAL CONNECTIONS, PLUG-IN RELAYS, ETC. 
The DC supply voltage is approximately

$$
\sqrt{2}(115)=162 \text { volts, }
$$

leaving the relay voltage at

$$
162-138=24 \text { volts, }
$$

which is sufficient to energize 1t. Obviously, then, removing the bypass from more of the 30-volt diodes reduces the relay voltage to zero, causing the relay to drop out and infitite a scram.

The other extreme condition occurs when all of the 30volt dlodes are shorted, and the relay voltage becomes

$$
162-18=134 \text { volts. }
$$

In actual practice the voltage will be lower, because the additional current drain will decrease the power supply voltage and increase the zener diode drop slightly at the same time. The relay coll is capable of withstanding this overcurrent for sustained periods because it is bolted to the aluminum chassis for heat sinking.

One normaliy-open contact on each of the individual scram relays (RYI through RY7) is shorted when 1ts switch is in the "BYPASS" position. These contacts are connected in series with a normally-open contact on the master relay and into the reactor scram system. A second set of normally-open contacts (on RYI through RY7) is used without the master relay to operate an external annunciator that signifles a nuclear scram. A contact on RY8 is also connected to an external annunclator that indlcates when less than three nuclear trips are in the "READY" state.

is

Indicator lamps are connected so that an amber light is on above any switch in the "BYPASS" position, while either a red or green light is on above any switch in the "READY" position. The green light, which indicates normal reactor conditions, is switched off and the red light switched on by a Form "C" contact (SPDT, break-before-make) on the individual trip relay (RYl through RY7). Thus, whenever a nuclear scram occurs, the lights tell the operator where it originated.

The relay system is fall-safe because normal reactor operating conditions keep all unbypassed relays energized. Failure or removal of a relay, or fallure of the DC power supply causes a scram. Prestartup tests of the nuclear trips guard against internally shorted zener diodes and stuck (or welded) contacts. 
This scram bypass system has operated satisfactorily at the Savannah River Laboratory for almost two years. It is the main nuclear scram panel in the Process Development Pile control system, and has been completely trouble-free since it was installed in February 1962.

\section{REFERENCES}

1. W. J. Woodward. A Versatile Electronlc Trip Device. USAEC Report DP-897, E. I. du Pont de Nemours \& Co., Savannah River Laboratory, Aiken, S. C. (1964).

Parts List (see Fig. 3)

\begin{tabular}{|c|c|}
\hline Part & Description \\
\hline $\mathrm{Cl}$ & Capacitor, $10 \mu_{f}-600$ VDC, G.E. $23 F 876$ \\
\hline$D I-4$ & Silicon Diode, $0.5 \mathrm{~A}-400 \mathrm{PIV}, 1 \mathrm{~N} 1084$ \\
\hline Fl & Fuse, 3A-125V, Type 3AG \\
\hline F2 & Fuse, 1-1/2A-125V, Type 3AG \\
\hline$L I-7$ & $\begin{array}{l}\text { Lamp, 130V-6w, G.E. 656, in Dialco socket } \\
\text { Assembly 19901-531 (Red Lens) }\end{array}$ \\
\hline L8- 14 & $\begin{array}{l}\text { Lamp, 130V-6W, G.E. } 656 \text {, in Dialco socket } \\
\text { Assemb1y 19901-532 (Green Lens) }\end{array}$ \\
\hline II5-2I & $\begin{array}{l}\text { Lamp, 130V-6W, G.E. 656, in Dialco socket } \\
\text { Assembly 19901-533 (Amber Lens) }\end{array}$ \\
\hline RYI-7 & $\begin{array}{l}\text { Relay, 3PDT, Il5 VAC, Potter \& Brumfield } \\
\text { KRP14A, in. Amphenol } 78-\mathrm{S}-11 \text { Socket }\end{array}$ \\
\hline RY8 & Relay, DPDT, 5K $\Omega$, Potter \& Brumfield LMII \\
\hline $\mathrm{S} 1-7$ & $\begin{array}{l}\text { Switch, 4PDT (I Pole Unused), Key-Operated, } \\
\text { Square "D" TSIK3 with TF \& TB Contact Blocks }\end{array}$ \\
\hline $\mathrm{T} 1$ & Transformer, $50 \mathrm{~W}$ Isolation, Stancor P6410 \\
\hline TB1, 3 & Barrier Strip, Cinch-Jones 8-142Y \\
\hline TB2 & Barrier Strip, Cinch-Jones 7-142Y \\
\hline $\mathrm{Zl-7}$ & Zener Diode, 30V-IW, Motorola IN303IA \\
\hline z8 & Zener Diode, $18 \mathrm{~V}-1 \mathrm{~W}$, Motorola $1 \mathrm{~N} 3026 \mathrm{~A}$ \\
\hline
\end{tabular}




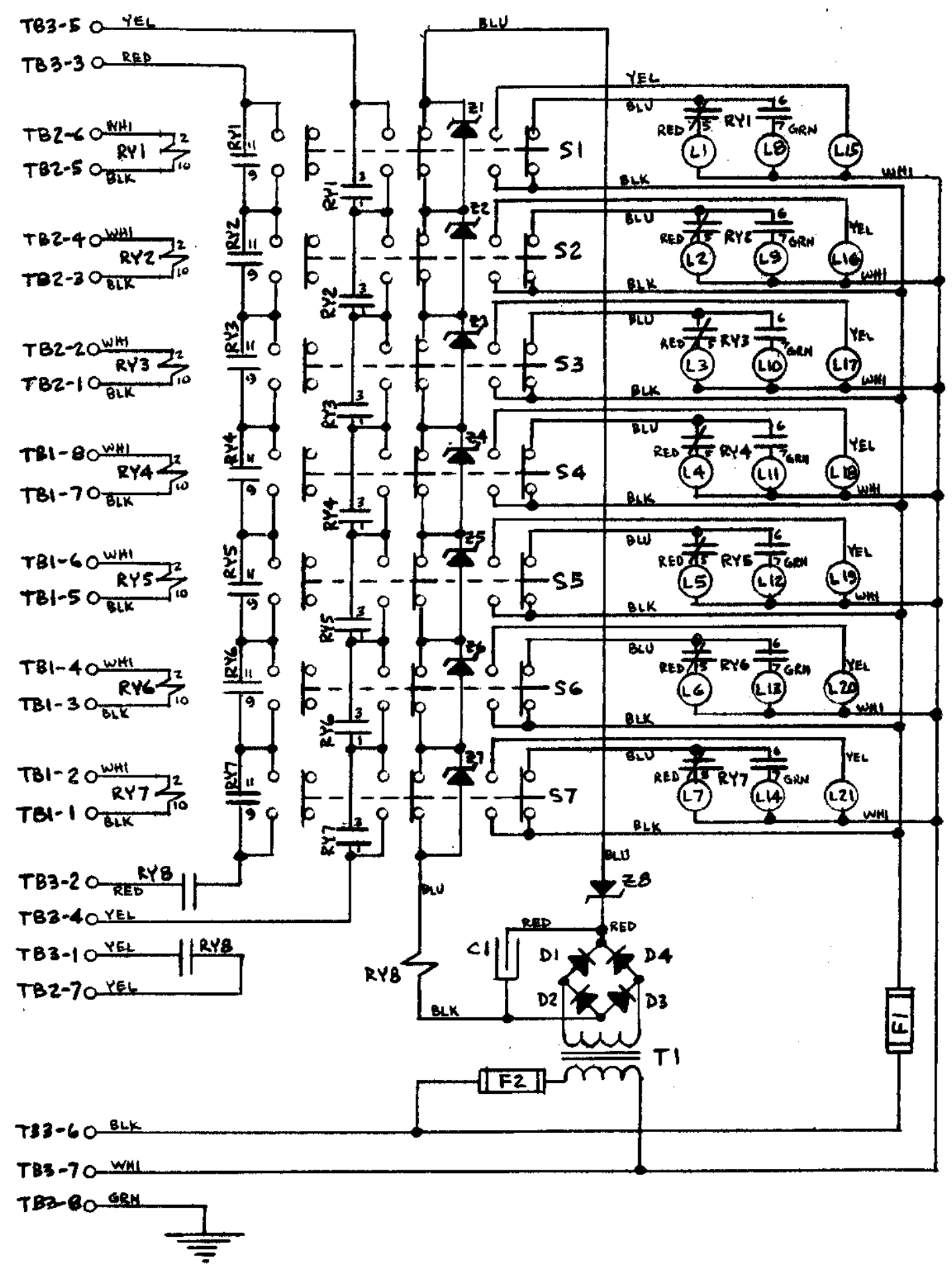

FIG. 3 SCHEMATIC DIAGRAM OF BYPASS SYSTEM 